\title{
Hour Times Millimole per Liter per Kilogram per Meter Squared
}

National Cancer Institute

\section{Source}

National Cancer Institute. Hour Times Millimole per Liter per Kilogram per Meter

Squared. NCI Thesaurus. Code C111220.

Hours times millimoles per liter, divided by kilograms per meter squared. 